\title{
The Challenges of Teaching EFL Listening in Iraqi (Kurdistan Region) Universities
}

\author{
Rauf Avci ${ }^{1, *}$, Natela Doghonadze ${ }^{2}$ \\ ${ }^{1}$ Education Faculty, Ishik University, Erbil, Iraq \\ ${ }^{2}$ Faculty of Education and Humanities, International Black Sea University, Georgia
}

Copyright $\bigcirc 2017$ by authors, all rights reserved. Authors agree that this article remains permanently open access under the terms of the Creative Commons Attribution License 4.0 International License

\begin{abstract}
The article is dedicated to the issue of teaching EFL listening in Kurdistan region of Iraq. The important role of listening skills in a FL learning is presented, and the difficulties of listening are analyzed, including language (vocabulary, grammar) and psychological (low motivation and self-confidence as well as a high level of listening anxiety) factors. The article involves a questionnaire survey with participation of 98 students from 8 universities in Kurdistan Region of Iraq and 28 teachers from 7 universities in the same region (universities mostly overlap, so totally 9 universities are involved). The survey shows that the level of listening anxiety among the students is quite high.
\end{abstract}

Keywords Listening Anxiety, Listening in L1, Second Language and Foreign Language, Pygmalion Effect, Motivation, Academic Performance

\section{Literature review: Listening in L1, Foreign Language and Second Language}

Listening plays a very important role in verbal communication. Rankin indicated that [29] among the four basic verbal communication skills (reading, writing, speaking and listening), most time is dedicated to listening: adult people spend 42 to $60 \%$ of their time on listening (babies spend $100 \%$ of their time on verbal communication listening, then step by step the percentage of speaking time increases, and only after kids go to school, the percentage of reading and writing increases). That shows the primary role of listening skills, which we use most of our time to communicate at school, at home and during free time, for instance, new generation spends more time watching movies, videos, news, lessons on the internet, and so on.

Purdy stated that [28] listening skills are the most significant competence skills for contacting other people. Listening is the first language skill developed in a baby. Even before being born the baby listens to mother's voice and can distinguish it among other voices. Babies who cannot yet speak recognize the pitch and perceive the emotions of the utterance, they try to distinguish familiar sound combinations in what they hear [34].

No oral communication can occur without listening. Not only do we listen to the interlocutor(s), but also do we listen to / monitor ourselves while speaking, to make some corrections, if necessary. One-sided speaking cannot occur if the speaker is sane: a speaker needs a listener, at least a remote one (listening on the telephone or radio), otherwise the act of speaking becomes meaningless (except, probably, a rehearsal held without listeners).

On the other hand, one-sided listening does occur, and often enough - listening to teacher's explanation or the lecture, to all sorts of recordings, while watching a movie, a TV program, a theatrical performance, etc.

A good speaker needs to be able to listen well and to have the metacognitive strategies for listening. In monologue speaking, the speaker has to preview the audience, their level of education, their background knowledge, to provide comprehensible for them input. In a dialogue, the speaker has to understand the interlocutor, to respond adequately. In a dialogue, trying to speak, unless listening comprehension has been achieved, may cause serious communication problems. Students whose listening comprehension skills are on a low level will experience high anxiety while speaking, afraid of saying something out of place. This, in turn, will lead to forgetting the words they know well, of turning to mother-tongue structures and internal translation, instead of speaking directly in the target language. "It leads to impairment in the ability to improvise in an unstructured and/or new situation. This results in stereotyped, habitual, and familiar approaches that may be maladaptive in the situation." [13, p.11].

While mastering the mother tongue, children spend hours daily on listening. Children not spoken to or, at least, not submitted to technical equipment transmitting human speech (telephone, radio, television, computer, or a record-player) cannot learn the native language. By the time when they go to school, children, like flying aces, have hundreds of hours' 
listening experience. Listening is also what they do best: while speaking they may have problems pronouncing certain phonemes, their sentences may be short, primitive and often ungrammatical, and their productive vocabulary is not too rich. However, while listening, they understand well more complex sentences than they can produce and discriminate the correct pronunciation from the incorrect one. Brown [28, p.33] brings an interesting example is his book. A little girl who said her name was "Litha", when the adult cooed her answer "Litha?" said "No, Litha", after which he guessed that her name was Liza.

So, naturally, listening to the mother tongue is normally not purposefully taught to school children. Listening comprehension in the native language for people is as natural as breathing (except those, who have listening impairment or mental problems). However, some schoolchildren better understand teacher's stories and explanations, while others may not understand deeply and correctly enough. The reason for that is that the listener normally makes some forecast of what $\mathrm{s} / \mathrm{he}$ is going to hear, that is why comprehension is sometimes wrong, based on false expectations [25]. In language art classes school children practice writing a summary of a story listened to, note-taking and then retelling based on the notes made and answering comprehension questions. This is, however, rather done for concentration of attention and the development of writing, speaking, summarizing and other cognitive skills. In reality some attention in these activities is paid to listening skills and strategies, too. In the mother tongue listening does not normally cause anxiety, except people who have trait anxiety and tend to be anxious too often. The lack of listening skills, caused mostly by the lack of training in second and especially foreign language causes not only a deficiency in these skills, but also anxiety in listening situations, due to the lack of self-confidence.

When children have problems of listening comprehension in the native tongue, it is usually parents who explain them the meaning (and children are normally not shy or afraid to ask to repeat or explain the utterance), and with time they develop (more often subconscious) strategies of listening comprehension. It is also interesting that either children or adults normally do not worry when they do not hear well or understand about $10 \%$ of the information they listen to. They feel quite comfortable with it, as they understand the speech on the whole $[10,12]$.

In second language teaching, besides the classroom, students are plunged in the target language environment (unless they purposefully avoid it, due to laziness or shyness), so they listen in the target language almost as much as the native speakers, thus, listening to a second language is not a big problem for them, either. However, at language lessons they do fulfill listening activities in order to sharpen their listening skills. Listening skills assessment, unlike mother tongue, is also part of their educational process.
While learning to a foreign language, students spend, probably, $20-30 \%$ of time listening to each other, the teacher and the recordings. As only recordings offer them authentic language, their experience of authentic listening in class is only about an hour or two a week, which is nothing, compared to L1 and ESL students. So, obviously, learning to listen efficiently in a foreign language is the most difficult task, which cannot be perfectly fulfilled without much out-of-class practice with the help of the radio, television, video, and computer. This can be done as homework (which again is quite limited in time) or on the student's initiative, which requires intrinsic motivation (not so many students are intrinsically motivated to learn a foreign language and to practice listening, which is, except listening to songs, a very hard work for them). Besides, unfortunately, listening comprehension strategies are seldom taught, so students often get stuck and abandon listening after they hear a couple of unfamiliar words.

While listening to a foreign language, anxiety influences foreign language learners' performance in a quite negative way $[15,20]$. The current studies examine the interplay of language difficulties: students who have comprehension difficulties with mother language; they are the same trouble in English as a foreign language [31]. But even students who have effective listening strategies in L1 not necessary are able to transfer them on L2 applications. Second language learners often feel stressed while both learning and using it, it especially concerns listening, as here they feel least confident [5]. The reason is they completely depend on the speaker's pronunciation peculiarities, his/her vocabulary and choice of structures, also they realize their experience in listening to a foreign language is not sufficient. Logically, listening anxiety has a negative effect on learner personal success, while applying the English language.

Stephen Krashen's [22, 23] theory of second language acquisition emphasized the role of listening in the native language acquisition as the main, in fact, in the period preceding literacy, the only source of comprehensible input. For second and especially foreign language acquisition reading is also important, as, in the majority of cases, learners start dealing with the target language when they already have some reading skills in the native language, which permits to develop target language reading skills faster and easier. However, listening is still critically important.

\section{Background Information}

Before the study, some information will be provided below to have a general perspective on the current condition of teaching listening skills in Iraq and on the concept of Pygmalion Effect. 


\section{Teaching Listening Skills in Iraqi Kurdistan}

Iraq was under British mandate during 1917-1932. After gaining independence in 1932, Iraq formed the Ministry of Education, among other governmental structures, and education management was strictly centralized. The only language of instruction was Arabic. In 1974 Kurdistan Region gained autonomy, after which some schools in the region were permitted to teach in Kurdish [1]. The political instability during the period of 1958-1979, the dictatorship of Saddam Hossein and 2003-2011 war had a traumatic effect on the development of Iraq, including its educational system [17,3].From 2011 the country is trying to restore and improve the educational system. Nowadays the language of instruction in higher education is Arabic for Arab areas and Kurdish for Kurdish area, except for the faculty of medicine and the engineering faculties where the language of instruction is often English. Final theses and doctoral theses are written in Arabic, with an abstract in English [9].

A large project initiated by UNESCO Iraq Office in 2011 has developed a new national curriculum, which requires teaching to be student-centered, applying whole-class and group work. Concerning foreign (mostly English) language teaching, Communicative Language Teaching (CLT) is recommended (Ahmed et al., [2]), however, a lot of teachers still use Grammar Translation Methods, concentrated on grammar and reading skills [3].

From 2014 to 2021 UNESCO is in the process of implementation of the "Education for peace and sustainable development", in the frames of which much help to Kurdish Regional Government as well as Iraqi Federal Government, especially in technical equipment of public schools. International companies contribute to the economic development of countries. They need educated employees with adequate level of English skills, which stimulates the growth of motivation of getting technical education and learning English [3, 4].

In the period of English rule, there were some private English schools opened in 1929 in the country, when the country gained independence, they were shut down, as the majority of teachers and students were not Iraqi citizens. Although nowadays there is certain prejudice towards English as the language of former colonizers as well as American invaders (Iraqi war of 2003-2011, attitude to which is not unanimous in the country), it has gained the reputation of worldwide prestige, as it provides profitable careers in the future $[1,2,3,4]$. Private schools, where tuition language is mainly English re-opened in the country in 2011.

In contemporary Iraqi context, English is taught as a foreign (not second) language, as there is no environment (to say nothing of radio, television and internet) of English beyond the educational institutions. It is taught in public schools starting with the third grade of primary school, which reveals that much attention is paid to it. In some private schools it is either taught from the first grade or tuition is completely in English. Irrespective much attention paid to teaching English, the country still lacks qualified teachers of English and the teaching methods used (especially in public schools) are too often outdated [1]. As Al Hamdany [3] stated, the students 'study' English, but do not 'learn' (or master) it.

On the other hand, Grajek [14] stated that Iraqi employers view the ability of universities' graduates to communicate in English among top skills. For a country in which unemployment level is high, it is essential to provide university graduates with skills required by the market. The US Embassy contributes to the improvement of the situation by opening language centers, equipping them, training teachers, offering up-to-date educational materials. The government and the universities are very much concerned about raising the English skills' level among the graduates.

If we view IELTS test statistics of Iraqi citizens who took the test in 2015 (assessed in a nine-band score), we will see that the mean points in listening are 5.5, while in reading they are 5.4, in writing -5.2 , and in speaking 5.6, or listening points are the highest after speaking [16].The scores are not too high, but even these scores do not reflect the real situation in the whole country, as this test is taken by the most educated people for visa reasons (getting jobs and/or education abroad).

Irrespective all efforts, the majority of Iraqi undergraduate students' listening skills are not developed on a satisfactory level, as shown in some researches $[6,24]$.The reasons are the lack of practice of authentic listening [6] and the lack (if not total absence) of listening strategies [24]. According to Bingol's [7] study held with 111 Iraqi (Kurdistan Region) undergraduate students, Iraqi students' main obstacles to listening comprehension are unfamiliar vocabulary and the speed of utterance.

Compared to the rest of Iraq, the situation with education in Kurdistan Region is relatively good. According to the education system in the Iraqi Kurdistan which is shaped in accordance with the British mandatory period in the region, the students who complete the curriculum in the end of the twelfth year and graduate from the high schools, take a university entrance exam in which English is given 5\% of the total grade and the English exam does not involve a listening part. Thus, schools do not pay sufficient attention to practicing listening skills. However, private universities in the area make it compulsory for students to pass the listening exam that is a part of the proficiency tests [1]. Natural enough, it is too difficult for school graduates to do so. On the other hand, among the Kurdish population the attitude towards English is better than towards the Arabic language, as it is viewed as an efficient tool for an academic career, employment, and informing the western world on the Kurdish issue. This is a good soil for teaching English [11, 30].

Kurdistan Regional Government (KRG) is doing much to improve the education in the region: $16 \%$ of the budget for 2013 was allocated for the education and higher education 
sectors. Private sector, which has to be licensed by the government, also contributes a lot to the development of education (between 2006 and 2013 they invested \$668 million in educational projects). This is certainly inspiring, but, to make the investments more efficient, it is necessary to investigate the most important problems and the potential ways of solving them [19].

Teaching English is one of the most challenging issues in the Iraqi Kurdistan region, whose capital is Erbil, since population there speaks three main different languages: Kurdish, Arabic and Turkmen, and some minor languages and dialects. Only Arabic alphabet, with its writing from right to left, unites the three, otherwise they are quite different. With population used to Arabic script, teaching any European language with Latin script and writing from left to right (including English) is not easy. An exception is the Northern Kurdish dialect Kurmanji, which uses a modified Latin alphabet [30]. Even while working with computers, educators face many problems, as certain adaptations are needed to be able to use the computer for both Latin and Arabic script. This fact makes it difficult for students and teachers (some of whom are native English speakers) to communicate with each other, but, in the case of teaching English as a foreign language, creates a motivation to use the language for communication among students of different ethnic groups. Still, as Ahmed et al. [2] stated, in Iraq as a part of the Arab world, low English proficiency level is a great obstacle for students as they have a visible difficulty in understanding written texts [2].

In 2003, when the degree of Kurdistan autonomy increased, private schools were re-introduced in the region. Many of them teach English intensively from the first grade, and some provide tuition completely in English. UNESCO opened their office in Erbil in 2007, which stimulates the development of education, including English teaching.

According to an annual trial test exam that is held by the Ishik University, which is called ITCO (abbreviation of the Ishik Test Competition Organization) taken by approximately 4000 students of 12 th grades and performed with the permission of the Ministry of Higher Education and Scientific Research in the Kurdistan Region, the level of English learning is not high enough [18].

The reasons lying behind the situation are several. Vernez, Culbertson, \& Constant [33, p.16] mentioned that many Kurdish children start schooling at a later age than they should according to the law. They have jotted down that yearly instructional time in the double-shift basic schools is 539 hours while in the single-shift schools; this amount has risen to 693 . Nonetheless, the given numbers are less than the OECD average amount of 968 and EU average amount of 965 for the year 2005 [27, p.369].

Besides the curriculum fulfillment problems, insufficient school buildings and instruction time, low quality of textbooks, outdated methods of teaching, deficit of teacher training, lack of updated documents, insufficient technical info and physical conditions of the classrooms in which 40-50 students try hard to study are some other troubles in front of the effective teaching and learning in the Iraqi Kurdistan [30].

According to Yahya [35], who studied the problems faced in the Kurdistan region, the results are mostly to do with the connected speech issues and the lack of suitable strategies (including listening skills) and insufficient general education level. Another research [1] supported what is said above. The average points of students taking the entrance exam are not too high due to the unstandardized English level. If their further education is in English, they usually need to study at preparatory school at the university, to be able to continue their studies in English.

A study on the effects of listening on the students' motivation, held in the Kurdistan region on 100 prep school students has shown that the majority of the participants agree that, as the students improve their perception of listening, their motivation towards language acquisition increases as well [36].

Table 1. The Impact of the Level of Listening Skills on Motivation

\begin{tabular}{|c|c|c|c|c|c|}
\hline \multicolumn{5}{|c|}{ Listening Motivation } \\
\hline \multirow{3}{*}{ Valid } & Frequency & Percent & Valid Percent & Cumulative Percent \\
\hline & Ambivalent & 11 & 11.0 & 11.0 & 11.0 \\
\cline { 2 - 7 } & Agree & 58 & 58.0 & 58.0 & 69.0 \\
\cline { 2 - 7 } & Strongly Agree & 31 & 31.0 & 31.0 & 100.0 \\
\cline { 2 - 7 } & Total & 100 & 100.0 & 100.0 & \\
\hline
\end{tabular}

$[36$, p.9]. 
According to the results given in the table above that was taken from the respective research, a total of $89.0 \%$ of the participants agree that improving listening skills of the learners provides motivation and inspiration depending on the interaction between teacher and learner, which is the result of Pygmalion Effect, in the process of acquiring language [36].

Koran's [21] study showed that teacher motivation helps to improve students' listening and speaking skills. Twenty five teachers in an Iraqi university were assessed by students, administration and themselves as having low, average and high motivation. Then one teacher was at random selected from each group, 55 students with approximately the same level of language skills were placed in their classes and taught listening and speaking, then their pre-, while- and post-experimental test results were compared. It was shown that the most motivated teacher's class made most progress, while the least motivated teacher's class - least progress.

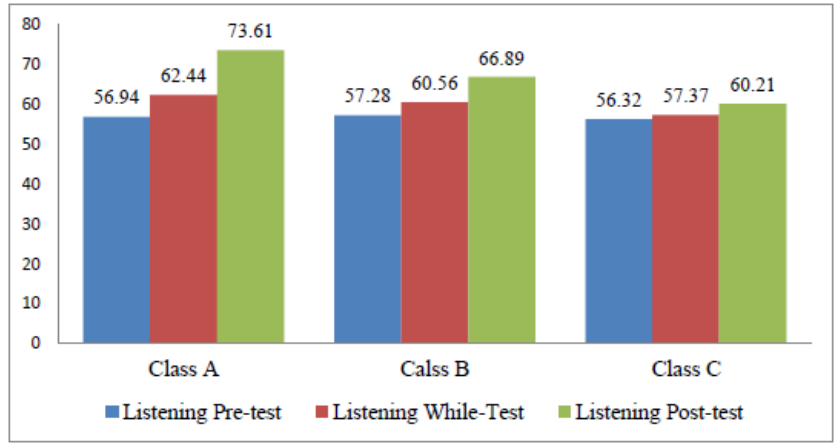

Figure 1. Average results of listening progress tests out of 100 points [21, p.138].

Highly motivated teachers are well-organized, choose creative teaching methods, encourage participation, and provide feedback, etc. Thus, they increase students' output in two main ways - directly (they apply more efficient teaching methods) and indirectly (they motivate students to work harder). Interaction between teacher and students is essential for efficient learning. When the level of positive expectation increases, the success eventually comes out as well. In other words, Pygmalion Effect is operated between teacher and student.

\section{Method}

The research questions were:

1) What is the level of undergraduate students' listening skills' level in Kurdistan Region (according to students' self-assessment)?

2) What is their listening anxiety level?

To answer these questions in this study, quantitative research methods, namely, a survey on listening anxiety among Iraqi undergraduate students and their teachers (Kurdistan Region), were used.

To do this, a measurement tool had to be selected and/or developed. The teachers' and students' questionnaires for the nation-wide survey were designed based on the literature analysis in the dissertation. They concerned students' listening anxiety level. To provide their reliability and content validity, the draft version of the questionnaire was applied with a group of 20 students and 10 teachers, not involved in the study. For the reliability of the results some synonymous items were suggested in order to see whether the answers to them by the same respondent would coincide. When it was not so, the items were omitted or reformulated. The teachers were also asked to provide feedback dealing with the clarity of the items. Eventually, the questionnaire for students involved 16 items that had to be assessed in 5-point Likert scale (from 1 - totally disagree to 5 - completely agree). The questionnaire for teachers was analogous (the items were reformulated like 'I am anxious' $\rightarrow$ 'The students are anxious", and 4 items dealing with teachers' awareness of Pygmalion Effect were added. After the teachers filled in the questionnaire, they were informed on its goal and were asked whether the items were relevant to the goal, to provide the content validity. A discussion followed, after which some items were removed or reformulated.

The questionnaire was held at various faculties in nine universities in the Kurdistan region in Iraq (seven of them coincided for the students and the teachers, while two were different), the participation was on a volunteer basis. It was available to the participants online for more than a month (from February 28 to April 6, 2017). 98 students and 28 teachers volunteered to participate.

\section{Sample}

The target community of the study was Iraqi undergraduate students from Kurdistan Region studying English as a foreign language. There are 19 recognized by state universities in the region; the total number of university students is 94,700 . The percentage of female students is $48 \%$ [26].

Students from eight (five public and three private) universities and teachers from seven universities (four state and three private) participated in the research, which is representative enough. On the other hand, 98 participant students of the survey constitute about $0.1 \%$, which is not too representative. The number of teachers was quite limited, too. The ratio of the genders is more or less representative of the whole region.

Participation in the study was voluntary. The teachers and students were informed that their answers would be anonymous and that at any moment they could quit the study if they found it somehow hurting them.

For the region-wide survey, the researcher published the questionnaire on Ishik University's official Facebook. Besides, Ishik University has memorandums of understanding with other Kurdistan Region universities. A network of connections exists among these universities, so 
the researcher addressed some English teachers from these universities to distribute his questionnaires among students and lecturers on paper as well.

Table 2. Kurdistan Region Universities' Survey Participant Students

\begin{tabular}{|c|c|c|c|c|}
\hline \multirow{2}{*}{ University } & \multirow{2}{*}{$\begin{array}{c}\text { Student } \\
\text { number }\end{array}$} & \multirow{2}{*}{ age } & \multicolumn{2}{|c|}{ gender } \\
\cline { 3 - 5 } & 7 & $17-21$ & 3 & 4 \\
\hline $\begin{array}{c}\text { American } \\
\text { University }\end{array}$ & 11 & $17-21$ & 4 & 7 \\
\hline $\begin{array}{c}\text { Basrah } \\
\text { University }\end{array}$ & 9 & $17-21$ & 5 & 4 \\
\hline Cihan University & 6 & $17-21$ & 1 & 5 \\
\hline $\begin{array}{c}\text { Halabja } \\
\text { University }\end{array}$ & 8 & $17-21$ & 3 & 5 \\
\hline $\begin{array}{c}\text { Kirkuk } \\
\text { University }\end{array}$ & 13 & $17-21$ & 5 & 8 \\
\hline Koya University & 31 & $17-21$ & 14 & 17 \\
\hline $\begin{array}{c}\text { Salahaddin } \\
\text { University }\end{array}$ & 98 & Mean age: 19 & 43 & 55 \\
\hline Erbil University & 13 & & & 5 \\
\hline Totally & \multicolumn{2}{|c|}{} \\
\hline
\end{tabular}

Table 3. Kurdistan Region Universities' Survey Participant Teachers

\begin{tabular}{|c|c|c|c|c|}
\hline \multirow{2}{*}{ University } & \multirow{2}{*}{$\begin{array}{c}\text { teacher } \\
\text { number }\end{array}$} & \multirow{2}{*}{$\begin{array}{c}\text { mean } \\
\text { experience }\end{array}$} & \multicolumn{2}{|c|}{ gender } \\
\cline { 4 - 5 } & 2 & 16 & 0 & 2 \\
\hline $\begin{array}{c}\text { Basrah } \\
\text { University }\end{array}$ & 3 & 7 & 2 & 1 \\
\hline Cihan university & 2 & 20 & 1 & 1 \\
\hline $\begin{array}{c}\text { Halabja } \\
\text { university }\end{array}$ & 1 & 17 & 0 & 1 \\
\hline $\begin{array}{c}\text { Kirkuk } \\
\text { University }\end{array}$ & 3 & 9 & 2 & 1 \\
\hline Koya University & 14 & 12 & 8 & 6 \\
\hline $\begin{array}{c}\text { Salahaddin } \\
\text { University }\end{array}$ & 3 & 7 & 2 & 1 \\
\hline $\begin{array}{c}\text { Lebanese } \\
\text { French }\end{array}$ & 28 & 12 & 15 & 13 \\
\hline University & Totally & & &
\end{tabular}

\section{Data Collection and Analysis}

The surveys were held both on paper and online and then summed up. The results presented in the dissertation are anonymous. The students were informed that the study findings could in no way impact their grades at university or personal lives.
Survey results were calculated and then transformed into tables, charts and figures. In the questionnaire survey, the overall regional (Iraqi Kurdistan) picture was analyzed.

\section{Ethical Issues}

The respondents were only volunteers. They knew that the results of the questionnaire would be anonymous and the results would in no way harm their professional reputation or studies. However, they were also informed that they could drop from it if they found some items of the questionnaire inappropriate for them.

\section{Kurdistan Region Questionnaire Survey on EFL Listening Anxiety and Teacher Role in Decreasing It}

The questionnaire survey dealt with listening anxiety level among Iraqi Kurdish students of EFL. The participants (students and teachers) had to assess 16 items which were analogous for students and teachers in a 5-point Likert scale format (1-totally disagree $\rightarrow 5$ - completely agree). The questionnaire was provided to the students both on-paper via their teachers and on-line via Facebook. As for the teachers, they did it online.

Some items in the questionnaires are positive statements (e.g., 'I am usually at ease during listening tests in my language class'), while others are in negative form (e.g., 'I am not nervous while listening to the foreign language in authentic situations'), not to provoke students to answer thoughtlessly. The respondents were told to answer as thoughtfully as they could. The questionnaires for the students were translated in their native tongues, to be well understood. Items 7 and 10 are synonymous, to see whether the answers of each given student are trustworthy. No answer-sheets were discarded, as the answers to these two items did not differ.

98 students from 8 universities participated. The results are presented in Table 4 . The number of students who gave the answer is given in the table. The mean of 4.0 or above reveals that the respondents agree with the statement, the answers equal to or below 3.0 reflects that the students disagree with the statement, while the answers between 3.0 and 4.0 deals with the respondents' hesitation. 
Table 4. Questionnaire Survey Results: Student Answers

\begin{tabular}{|c|c|c|c|c|c|c|c|}
\hline Item \# & Item / response / student number who chose the response & 1 & 2 & 3 & 4 & 5 & $\begin{array}{r}\text { Mean } \\
\text { point }\end{array}$ \\
\hline 1 & I am usually at ease during listening tests in my language class. & 26 & 36 & 32 & 4 & 0 & 2.14 \\
\hline 2 & I am not nervous while listening to the foreign language in authentic situations & 21 & 42 & 16 & 17 & 2 & 2.30 \\
\hline 3 & I feel confident when I listen to recordings in foreign language class. & 21 & 51 & 18 & 7 & 1 & 2.08 \\
\hline 4 & I feel confident when I listen to my teacher and classmates in foreign language class & 40 & 37 & 9 & 8 & 4 & 1.99 \\
\hline 5 & I feel very self - confident when listening to the foreign language in class. & 30 & 39 & 20 & 7 & 2 & 2.10 \\
\hline 6 & It frightens me when I don't understand what the teacher is saying in the foreign language. & 4 & 6 & 5 & 46 & 37 & 4.08 \\
\hline 7 & I keep thinking that the other students are better at listening than I am. & 1 & 3 & 10 & 38 & 46 & 4.28 \\
\hline 8 & While listening to a foreign language, I can get so nervous I forget things I know. & 4 & 4 & 14 & 37 & 39 & 4.05 \\
\hline 9 & Even if I am well prepared for the lesson, I feel anxious while listening. & 7 & 8 & 4 & 38 & 41 & 4.0 \\
\hline 10 & I always feel that other students understand while listening to the foreign language better than I do. & 2 & 4 & 4 & 44 & 44 & 4.27 \\
\hline 11 & The speakers in recordings speak so quickly that I worry about getting left behind. & 2 & 3 & 5 & 50 & 38 & 4.25 \\
\hline 12 & When the speakers do not speak very clearly, I worry about not being able to understand them. & 2 & 8 & 8 & 48 & 32 & 4.43 \\
\hline 13 & When the speakers use language, I worry about not understanding them. & 2 & 6 & 4 & 50 & 36 & 4.14 \\
\hline 14 & When the topic is not very familiar, I worry about not understanding the text. & 3 & 6 & 6 & 51 & 32 & 4.05 \\
\hline 15 & I feel more tense and nervous listening than while speaking, reading or writing. & 4 & 7 & 2 & 45 & 40 & 4.12 \\
\hline 16 & $\begin{array}{l}\text { I get nervous when I don't understand every word the language teacher / the speakers in the } \\
\text { recording use. }\end{array}$ & 6 & 6 & 3 & 41 & 42 & 4.09 \\
\hline
\end{tabular}

The statements that express the absence of students' anxiety (items 1-5 ) all received low points, which means that students' anxiety is quite high (1.99-2.30). The anxiety is especially high in the classroom (1.99 - item 4), and lower in authentic situations $(2.30$ - item 2$)$, which may mean that students are afraid of assessments of the people they know (teacher and classmates). When they know that nobody is assessing them, they feel more peaceful.

On the other hand, statements which dealt with existing anxiety (items 6-16) yielded high results (4.0- 4.43), which again means that students' anxiety is quite high. Least anxious students are when they are prepared for the lesson (4.0 - item 9), and they are most anxious about not understanding the other speaker due to his/her unclear speech (4.43 - item 12). The declining order of listening anxiety of the respondent deals with:

- Unclear speech (4.43)

- Comparison to other students $(4.28$ / 4.27)

- $\quad$ Speed of speech (4.25)

- Complicated language (4.14)

- Understanding every word (4.09)

- Teacher's speech (4.08)

- $\quad$ Topic (4.05)

- Being prepared for the lesson (4.0)
It is possible to see that comparison to other students, which can be regulated with the help of Pygmalion Effect, stands the second in the list. Of course, it is impossible to make conclusions about the whole region with a sample of 98 students, but certain trends are visible.

The students supported the statement (item 15) that they are more anxious while listening than when they are speaking, reading or writing (4.12). Some of them (item 8) get so nervous that do not understand things that they know (4.05). This is easy to explain: both psychologically and linguistically (total dependence on the interlocutor for his / her clarity of speech, accent, rate, vocabulary and grammar, no visual support or possibility to elicit the meaning from the interlocutor in case of audio recorded speech) listening comprehension is very complicated.

To make the obtained results more trustworthy, an analogous questionnaire was offered to English teachers working at Iraqi universities of Kurdistan Region. 28 teachers from 7 universities, mostly the same ones from which the students come, but some different, too volunteered to answer the questionnaire. Teachers' view are more professional, besides, they indirectly involve a larger number of participants (i.e., their students), thus, making the survey results more objective. 
Table 5. Questionnaire Survey Results: Teacher Answers

\begin{tabular}{|c|c|c|c|c|c|c|c|}
\hline Item \# & item & 1 & 2 & 3 & 4 & 5 & $\begin{array}{l}\text { Mean } \\
\text { point }\end{array}$ \\
\hline 1 & Students are usually at ease during listening tests in my language class. & 9 & 7 & 5 & 6 & 1 & 2.39 \\
\hline 3 & Students feel confident when they listen to recordings in foreign language class. & 9 & 6 & 5 & 3 & 5 & 2.61 \\
\hline 4 & Students feel confident when they listen to the teacher and classmates in foreign language class & 6 & 7 & 6 & 5 & 4 & 2.79 \\
\hline 6 & It frightens students when they don't understand what the teacher is saying in the foreign language. & 0 & 2 & 5 & 10 & 11 & 4.07 \\
\hline 7 & Students keep thinking that the other students are better at listening than I am. & 1 & 1 & 5 & 11 & 10 & 4.0 \\
\hline 8 & While listening to a foreign language, students can get so nervous they forget things they know. & 0 & 2 & 4 & 10 & 12 & 4.14 \\
\hline 9 & Even if a student is well prepared for the lesson, she/he feels anxious while listening. & 1 & 1 & 4 & 11 & 11 & 4.07 \\
\hline 10 & $\begin{array}{l}\text { Students always feel that other students understand while listening to the foreign language better } \\
\text { than they do. }\end{array}$ & 0 & 3 & 4 & 12 & 9 & 3.96 \\
\hline 11 & The speakers in recordings speak so quickly that students worry about getting left behind. & 0 & 1 & 4 & 10 & 13 & 4.25 \\
\hline 12 & $\begin{array}{l}\text { When the speakers do not speak very clearly, students worry about not being able to understand } \\
\text { them. }\end{array}$ & 0 & 0 & 3 & 7 & 18 & 4.54 \\
\hline 13 & When the speakers use complicated language, students worry about not understanding them. & 0 & 1 & 4 & 11 & 12 & 4.21 \\
\hline 14 & When the topic is not very familiar, students worry about not understanding the text. & 1 & 1 & 4 & 12 & 10 & 4.04 \\
\hline 15 & Students feel more tense and nervous listening than while speaking, reading or writing. & 1 & 1 & 3 & 10 & 13 & 4.18 \\
\hline 16 & $\begin{array}{c}\text { Students get nervous when they don't understand every word the language teacher / the speakers in } \\
\text { the recording say. }\end{array}$ & 0 & 2 & 2 & 10 & 13 & 4.11 \\
\hline 17 & If I treat students as able language learners, their anxiety will decrease. & 2 & 2 & 3 & 7 & 14 & 4.14 \\
\hline 18 & Lower anxiety will help improve students' listening comprehension & 0 & 2 & 4 & 11 & 11 & 4.04 \\
\hline 19 & $\begin{array}{l}\text { If I tell students in the process of listening activities that they can do well, their level of listening } \\
\text { skills will increase. }\end{array}$ & 0 & 2 & 5 & 11 & 10 & 4.04 \\
\hline
\end{tabular}

Similarly to the students, the teachers disagree with the statement that their listening anxiety is low (items 1-5: mean results 2.29-2.79 points).

Also similarly to the students, teachers agree with the statement that students' listening anxiety is high (items 6-14): mean results from 3.96 to 4.54 . The declining order of listening anxiety, in teachers' view, deals with:

- Unclear speech (4.54)

- $\quad$ Speed of speech (4.25)

- Complicated language (4.21)

- Understanding every word (4.11)

- Teacher's speech (4.07) / Being prepared for the lesson (4.07)

- $\quad$ Topic (4.04)

- Comparison to other students $(3.96 / 4.0)$

It is easy to notice that the order in which the students' anxiety declines as assessed by the teachers is almost the same as in the students' answers.

The students supported the statement (item 15) that they are more anxious while listening than when they are speaking, reading or writing (4.18). Some of them (item 8) get so nervous that do not understand things that they know (4.14).

Items 17-20 deal with teachers' awareness with the ideas of Pygmalion Effect is high: their answers are between 4.0 and 4.14. The researcher consciously did not include the term 'Pygmalion Effect' in the questionnaire, as his goal was not to find out whether teachers know the term, but whether they share the ideas.

\section{Conclusions}

The questionnaire survey held with 98 students and 28 teachers from 8 universities in Iraqi Kurdistan Region has shown that Language learners' listening skill level does not correspond to international requirements. Listening anxiety constitutes a real problem for the respondents.

\section{REFERENCES}

[1] Ahmed, H. A. (1989). The Role of Attitudes and Motivation in Teaching and Learning Foreign Languages: A theoretical and empirical investigation into the teaching and learning of English in Iraqi preparatory schools. PhD Thesis. Stirling, UK: University of Stirling.

[2] Ahmed, H. H., Puteh-Behak, F., \& Sidek, H. M. (2015). Examining EFL secondary reading curriculum in Iraqi Kurdistan: A review. Journal of Applied Sciences, 15(3), p. 
377-391.

[3] Al Hamdany, H. (2012). In-depth debate into language and culture. European Scientific Journal, 8, 18, p. 79-89.

[4] Al Tuhafi, H. (2017). A narrative inquiry: Iraqi secondary teachers of English experiences with Communicative Language Teaching (CLT) approach in Iraq. Research Proposal. Melbourne, Australia: Deakin University. Retrieved March 25, 2017 from

http://www.academia.edu/31836299/A_narrative_inquiry_Ira qi_secondary_teachers_of_English_experiences_with_Comm unicative_Language_Teaching_CLT_ approach_in_Iraq

[5] Bailey, K.M. (1983). Competitiveness and anxiety in adult second language learning: Looking at and through the diary studies. In H. W. Seliger \& M. H. Long (Eds.). Classroom-Oriented Research in Second Language Acquisition (p. 67-102). Rowley, MA: Newbury House.

[6] Basim, Y. (2007). Identifying the advanced Iraqi EFL learners' obstacles in comprehending live speech and their pedagogical implications. Tikrit University Journal for Humanities, 14(8), p. 20-56

[7] Bingol, M.A. (2015). Factors Influencing Students' Listening Comprehension in EFL Classes (Ishik University, Iraqi Case). MA Thesis. Tbilisi: International Black Sea University.

[8] Brown, H.D. (2000). Principles of Language Learning and Teaching (4th edition). Englewood Cliffs, NJ: Prentice Hall Regents.

[9] Country Module. (2012) Iraq, Nuffic, 3rd edition, version 1. Netherlands Organization for International Cooperation in Higher Education, Information about the structure of the education system of Iraq and the evaluation of degrees obtained in Iraq. Retrieved March 20, 2017 from $<$ www.nuffic.nl/en/files/.../country-modules/country-moduleiraq.pdf $>$

[10] Dunkel, P. (1991). Listening in the native and second / foreign language: Toward an integration of research and practice. TESOL Quarterly, 25, 3, 431-457.

[11] Dunlop, W.G. (2015). Iraq's Arabs and Kurds have no common language. Retrieved April 10, 2017 from http://www.middle-east-online.com/english/?id=6693

[12] Faerch, C. \& Kasper, G. (1986). The role of comprehension in second language learning. Applied Linguistics, 7(3), p. 257-274.

[13] Gaier, R.L. (1952). Selected personality variables and the learning process. Psychological Monographs, 66 (349), p. $1-28$.

[14] Grajek, M. (2017). Iraqi Universities Focus on Teaching English. Retrieved April 20, 2017 from http://www.al-fanarmedia.org/2017/01/iraqi-universities-focu s-teaching-english/

[15] Horwitz, E. (1991). Preliminary evidence for the reliability and validity of a foreign language anxiety scale, p. 37-39. In Horwitz, E. \& Young, D. (Eds.). Language Anxiety: From Theory and Research to Classroom Implications. Englewood Cliffs, N.J.: Prentice Hall.

[16] IELTS. (2015). Test taker performance 2015. Retrieved March 15,2017 from

https://www.ielts.org/teaching-and-research/test-taker-perfor mance

[17] Isakhan, B. (2012). Democracy in Iraq: History, Politics, Discourse. London: Ashgate.

[18] Ishik Newsletter. (2017). ITCO'17 was taken by the high school senior students. Retrieved April 20, 2017 from http://www.ishik.edu.iq/itco17-was-taken-by-the-high-school -senior-students/

[19] Knowledge is Power: Education. (2013). Retrieved March 20, 2017 from

http://investingroup.org/review/246/knowledge-is-power-edu cation-kurdistan/

[20] Kondo, D.S. and Ling, Y.Y. (2004). Strategies for coping with language anxiety: The case of students of English in Japan. English Language Teaching Journal, 58 (3), p. 258-265.

[21] Koran, S. (2016). The Effect of Teacher Motivation on University Student's Speaking and Listening Skills in English as a Foreign Language (Iraqi Case). PhD dissertation. Tbilisi: International Black Sea University.

[22] Krashen, S.D. (1985). The Input Hypothesis. New York: Longman.

[23] Krashen, S.D. (1995). The Input Hypothesis: Issues and Implications. New York: Longman.

[24] Krebt, D.M. (2013). The effect of proposed teaching listening strategies programme on Iraqi EFL university students listening comprehension. Al-USTATH, 206, 2, p. 1-26.

[25] McRoy, S. \& Hirst, G. (1995). The repair of speech act misunderstandings by abductive inference. Computational Linguistics, 21, 4, p. 435-478.

[26] Ministry of Higher Education and Scientific Research, Kurdistan Region (2017). Higher Education in Kurdistan Region. Retrieved March 20, 2017 from http://www.mhe-krg.org/node/3332

[27] OECD (2007). Education at a Glance. OECD Indicators. Paris: OECD.

[28] Purdy, M. (1997). What is listening? (p. 1-21). In Murdy, M. \& Borisoff, D. (eds.). Listening in Everyday Life: A Personal and Professional Approach. Lanham, New York, London: University Press in America, Inc.

[29] Rankin, P.T. (1928). The importance of listening ability. The English Journal, 17(8), p. 623-630.

[30] Sofi-Karim, M. (2015). English Language Teaching in the Kurdistan Region of Iraq. MA Thesis. Webster University.

[31] Sparks, R. L. \& Ganschow, L. (1991). Foreign language learning differences: Affective or native language aptitude differences? The Modern Language Journal, 75, p. 3-16.

[32] UNESCO. (2015). UNESCO, KRG Ministry of Education agrees on setting up new planning mechanism. Retrieved March 25, 2017 from $\mathrm{http}: / /$ reliefweb.int/report/iraq/unesco-krg-ministry-education -agree-setting-new-planning-mechanism

[33] Vernez, G., Culbertson, S., \& Constant, L. (2014). Strategic priorities for improving access to quality education in the Kurdistan Region-Iraq. Retrieved March 20, 2017 from http://www.rand.org/content/dam/rand/pubs/monographs/MG 


\section{0/MG1140-1/RAND_MG1140-1.pdf 17}

[34] Wisdom, S.S. \& Friedland, B.Z. (1971). Pre-Verbal Infants' Selective Responses for Different Levels of Auditory Complexity and Language Redundancy. Department of Health, Education and Welfare. Washington, D.C.: Maternal \& Child Health Services, Eastern Psychological Association.

[35] Yahya, B. (2007). Identifying the Advanced Iraqi EFL
Learners' Obstacles in Comprehending Live Speech and their Pedagogical Implications. Journal of Tikrit University for the Humanities, 14 (8), p. 463-499.

[36] Yildiz, N., \& Albay, M. (2015). The Role of Listening Skills in Developing Communicative Competence: A Case Study in the Language Classroom. International Journal of Social Sciences \& Educational Studies, 2, 2, p. 4-11. 